\title{
Determination of Work Index of Gyel-Bukuru Columbite Ore in Plateau State, Nigeria
}

\author{
Oladunni Oyelola Alabi ${ }^{*}$, Shehu Aliyu Yaro², George Thomas Dungka², Ferdinand Asuke², \\ Emmanuel Toi Dauda ${ }^{2}$ \\ ${ }^{1}$ National Metallurgical Development Centre, Jos, Plateau State, Nigeria \\ ${ }^{2}$ Metallurgical and Materials Engineering Department, Ahmadu Bello University, Zaria, Nigeria \\ Email: oladunni69alabi@yahoo.com
}

Received 27 March 2015; accepted 23 May 2015; published 26 May 2015

Copyright (C) 2015 by authors and Scientific Research Publishing Inc.

This work is licensed under the Creative Commons Attribution International License (CC BY).

http://creativecommons.org/licenses/by/4.0/

(c) (i) Open Access

\begin{abstract}
Determination of the work index of Gyel-Buruku columbite ore sample in Plateau state, Nigeria, was investigated. The sample of the columbite ore was sourced from Gyel village in Jos East Local Government Area of Plateau state, Nigeria. The "reference ores (granites)" samples were sourced from Jiche and Gurum villages of Plateau state respectively. The reference ores and columbite ore of known weights were ground and pulverized. $80 \%$ passing size for the columbite ore, Jiche and Gurum granites samples was obtained at $100 \mu \mathrm{m}$ sieve size for the feeds and products respectively. The work indexes of reference ores i.e. Jiche and Gurum granites were used to calculate the work index of the Gyel columbite ore sample. The values of $3.42 \mathrm{kWh} /$ ton and $2.72 \mathrm{kWh} /$ ton were obtained respectively for the two different reference granites ores samples used and $3.07 \mathrm{kWh} /$ ton was calculated as their average and determined as the value of the work index of the Gyel-Bukuru columbite ore sample. This work index value obtained for the Gyel-Buruku columbite ore sample lies favourably within the work indexes of $3.94-\mathbf{1 0 . 8 1} \mathbf{k W h} /$ ton for columbite minerals sighted in the literatures.
\end{abstract}

\section{Keywords}

Work Index, Gyel Columbite Ore, Modified, Reference Minerals

\section{Introduction}

Nigeria is one of the countries in the world blessed with abundant solid mineral deposits; some of these have ${ }^{*}$ Corresponding author. of Gyel-Bukuru Columbite Ore in Plateau State, Nigeria. Journal of Minerals and Materials Characterization and Engineering, 3, 194-203. http://dx.doi.org/10.4236/immce.2015.33022 
been fully explored and their quantum is ascertained while further investigation is required to determine the quantum of the occurrence of others not yet listed. Those known to exist in commercial quantities include iron ore, cassiterite, columbite, tantalite, titanite, rutile, feldspar, limestone, lead, zinc, uranium, quartz and mineral fuel like coal etc. These industrial minerals cut across the entire states of the country [1].

The mineralization of the above-mentioned chemical compounds originated partly from the rocks of the basement complex which bear evidence of an exceedingly long history; they suffered greater or lesser degrees of alteration by heat and stress in the crust of the earth; they have been folded and crumpled, raised into mountain ranges and worn down by the agents of denudation to a gentle relief. As they are seen now, they cover four large areas in Nigeria, and extend far into the neighbouring territories. The most extensive expanse lies north of the rivers Niger and Benue and includes most of Sokoto, Kaduna, Kano, Bauchi, Plateau, and Niger states. Two groups of the granites are distinguished from this basement complex in Nigeria: the older and the younger granites. The older granites are widespread, and being resistant rocks, they give rise to the picturesque groups of smoothly domed hills that diversify the landscape. With the granites there are associated pegmatites, which in places contain small but occasionally workable amounts of tinstone and columbite-tantalite. The younger granites containing tinstone and columbite are found chiefly in Plateau, Kano, Kaduna, Bauchi and Benue states, where they form rugged hills, such as those seen near Jos. The valuable deposits of these minerals have been formed from the disintegration by weathering of the granites, and the concentration of the ore minerals in stream beds, either of the present day or of earlier geological periods. Small quantities of wolfram also occur in certain younger granites, and some contain the potentially valuable radio-active and pyrochlore minerals [1] [2].

The mineral columbite and others alike are strategic to some extend in the development of iron and steel, and other metallurgical industrial subsector of the economy for their usefulness as alloying elements in strengthening the physical and chemical properties of the metallurgical materials. Hence, on the basis of this, the Federal Government of Nigeria in its 1971 national planning to industrialize the nation, established the Aladja and Ajaokuta steel plants with the hope that non-ferrous metals like tin, tantalum, titanium, niobium, manganese, lead, zinc, copper, chromium, vanadium, etc. which are rare and expensive to import can be sourced locally, mined and extracted their utilization in the nation iron and steel plants and others metallurgical allied companies [1]-[3].

Hence, the rare and expensive nature of the above-mentioned alloying elements prompts this research work on "Determination of Work Index of Gyel-Bukuru Columbite Ore in Plateau State, Nigeria" as panacea for the development of a process route for the beneficiation of the ore deposit to metallurgical grade that can be used as alloying elements for local iron and steel plans.

\section{Theoretical Consideration for Comminution Process (Work Index)}

There are many theories of comminution, but paramount importance to this work is the modified Bond's equation called Berry and Bruce comparative Bond's equation that was used to determine the work index of the ore. Work index is the comminution parameter which expresses the resistance of material to crushing and grinding; it is the kilowatt hour per short-ton required to reduce the material from theoretically infinite feed size to $80 \%$ passing $100 \mu \mathrm{m}$ [4]. Table 1 gives the work index of some minerals ores samples.

Table 1. Gives the work index of some minerals ores samples.

\begin{tabular}{|c|c|c|c|}
\hline Material & Work index & Material & Work index \\
\hline Barite & $4.28-6.24$ & Fluorspar & $2.98-9.76$ \\
\hline Bauxite & $2.38-9.45$ & Granite & $2.68-15.13$ \\
\hline Coal & $1.63-11.37$ & Graphite & $1.75-45.03$ \\
\hline Dolomite & $2.82-11.27$ & Limestone & $2.69-11.61$ \\
\hline Emery & $3.48-58.18$ & Quartzite & $2.71-12.18$ \\
\hline Columbite & $3.94-10.81$ & Titanium ore & $4.23-11.88$ \\
\hline Tantalite & $3.6-11.90$ & Silica sand & $2.65-16.46$ \\
\hline Soba-Wanka Pyrochlore Coltan & 4.79 on the average & & \\
\hline
\end{tabular}

Source: [1] [2] [4]. 
From Berry and Bruce (1966) using Bond's law in Yaro and Thomas (2009), the work index of an ore can be determined by comparing its grindability:

$$
\begin{gathered}
W_{r}=W_{t}=W_{i r}\left[\frac{10}{\sqrt{P_{r}}}-\frac{10}{\sqrt{F_{r}}}\right]=W_{i t}\left[\frac{10}{\sqrt{P_{t}}}-\frac{10}{\sqrt{F_{t}}}\right] \\
\text { hence, } W_{i t}=W_{i r}\left[\frac{10}{\sqrt{P_{r}}}-\frac{10}{\sqrt{F_{r}}}\right] /\left[\frac{10}{\sqrt{P_{t}}}-\frac{10}{\sqrt{F_{t}}}\right]
\end{gathered}
$$

where $W_{r}=$ Work input of reference ore; $W_{t}=$ Work input of test ore; $W_{i r}=$ Work index of reference ;

$$
\begin{gathered}
\qquad W_{i t}=\text { Work index of test } \\
P_{r}=80 \% \text { of Product (reference ore) passes; } P_{t}=80 \% \text { of Product (test ore) passes ; } \\
F_{r}=80 \% \text { of feed(reference ore) passes ; } F_{t}=80 \% \text { of feed(test ore) passes }
\end{gathered}
$$

Hence, the needs to determine the energy required in grinding an ore from the run-off mines to its liberation size prior to process to prevent over grinding or under grinding and to enhance the selection of appropriate grinding equipment cannot be overemphasized. In short, the textural relationship between minerals within the matrix of an ore and their relation to process selection requires the determination of their liberation sizes. This is the size to which an ore must be crushed or ground in order to produce separate particles of either valuable or gangue mineral that can be removed from the ore (as concentrate or tailings) with an acceptable efficiency by a commercial unit process [5].

The most widely used parameter to measure ore grindability is the Bond work index, $W_{i}[6]$. Work index is the energy required in $\mathrm{kWh} / \mathrm{short}$-ton to reduce a given material from theoretically infinite size to $80 \%$ passing size, 100 microns [7]. The determination of work index using Bond's method can be compared to the method of determining it by Berry and Bruce (1966) known as the comparative method [8]. This method requires the use of reference ore of known grindability.

\section{Materials and Method}

\subsection{Materials}

$200 \mathrm{~kg}$ sample of columbite ore of which $50 \mathrm{~kg}$ of the sample used in this research work was obtained from Gyel columbite mineral ore deposit site at various spots 7 meters apart and about seven (7) kilometer off Bukuru-Jos express road. The granites samples used as reference ores respectively were sourced from Jiche-Hill station, Government house, Jos and Gurum in Mile seven (7) hill, behind NEPA exchange station Jos, Plateau state using cone and quartering sampling method.

\subsection{Method}

The sample of the reference ore was broken manually with a sledge hammer to provide required size acceptable as feed to the Denver laboratory jaw crusher. The sample was crushed and pulverized, part of the pulverized samples were weighed for sieve analysis. The modified Bond's method of determining the network index of ore involves use of reference ore of which grindability is known. The procedure is as follows.

1) $100 \mathrm{~g}$ each of samples of the ore under test and the reference ore were crushed and pulverized in the laboratory mill machine for an hour,

2) The samples of test and reference ores were taken and sized by sieving into a number of size fractions using the automatic sieve shaker for 15 minutes.

3) Each size fractions of the test and the reference ores were weighed and the value noted as "feed".

4) The "feed" test and reference ores were each gathered together and introduced into the Laboratory ball milling machine and ground for 1 hour.

5) The test and the reference ores from the laboratory ball mill machine were sized and each sieve fraction was weighed and the value noted as the product or discharge [9].

6) Sieve analysis. 
The ground samples were sieved into the following sieve size fractions; $+1400 \mu \mathrm{m},-1400+1000 \mu \mathrm{m},-1000$ $+710 \mu \mathrm{m},-710+500 \mu \mathrm{m},-500+355 \mu \mathrm{m},-355+250 \mu \mathrm{m},-250+180 \mu \mathrm{m},-180+125 \mu \mathrm{m},-125+90 \mu \mathrm{m}$, $-90+63 \mu \mathrm{m},-63 \mu \mathrm{m}$ using Denver automatic sieve shaker for 15 minutes.

\section{Results and Discussion}

\subsection{Results}

\section{(A) Test Ore (Gyel Columbite)/References (Granites) as Feeds to the Ball Mill}

Table 2 gives the sieve analysis result of the feed to ball mill of test ore (columbite) and Figure 1 is the graph plotted showing sieve sizes against cumulative percentage retained and cumulative percentage passing of test ore.

Calculation using the values in Table 2

If $500 \mu \mathrm{m}=83.719$

Then $X=80 \%$

Using Gaudin Schumann Expression

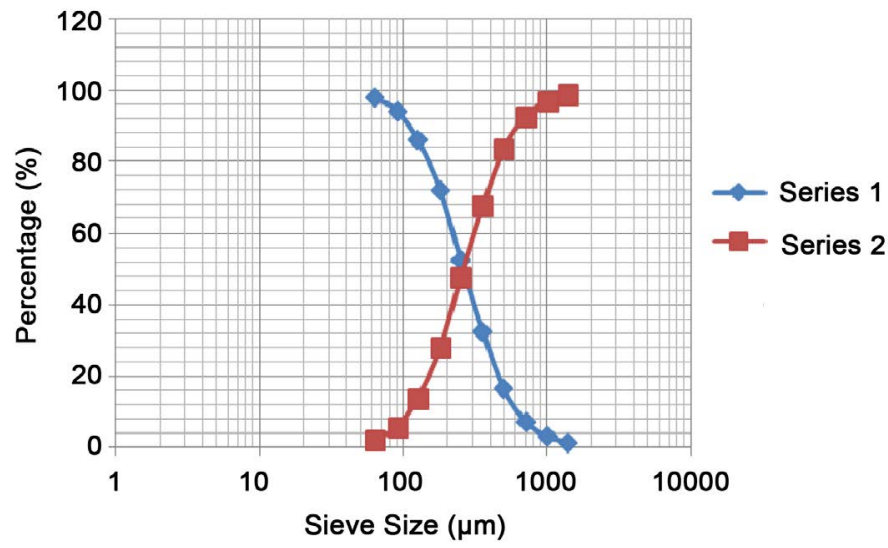

Figure 1. Shows sieve size $(\mu \mathrm{m})$ against cumulative \% retained and cumulative \% passing of the Gyel columbite feed to the ball mill.

Table 2. Sieve analysis of crude sample of Gyel columbite ore (feed to the ball mill).

\begin{tabular}{ccccc}
\hline Sieve sizes $(\mu \mathrm{m})$ & Weight retained $(\mathrm{g})$ & \% Weight retained & Cumulative \% weight retained & Cumulative \% weight passing \\
\hline+1400 & 1.31 & 1.312 & 1.312 & 98.688 \\
$-1400+1000$ & 1.62 & 1.622 & 2.934 & 97.066 \\
$-1000+710$ & 4.20 & 4.205 & 7.139 & 92.861 \\
$-710+500$ & 9.13 & 9.142 & 16.281 & 83.719 \\
$-500+355$ & 16.20 & 16.221 & 32.502 & 67.498 \\
$-355+250$ & 19.81 & 19.836 & 52.338 & 47.662 \\
$-250+180$ & 19.60 & 19.626 & 71.964 & 28.036 \\
$-180+125$ & 14.31 & 14.329 & 86.293 & 13.707 \\
$-125+90$ & 8.01 & 8.020 & 94.313 & 5.687 \\
$-90+63$ & 3.86 & 3.865 & 98.178 & 1.822 \\
-63 & 1.82 & 1.822 & 100.00 & 0.00 \\
\end{tabular}




$$
\begin{gathered}
P(X)=100[X / K]^{\alpha} \\
\alpha=\frac{\log P\left(X_{2}\right)-P\left(X_{1}\right)}{\log \left(X_{2}\right)-\log \left(X_{1}\right)} \\
\text { Size }_{2}=\frac{\left(\text { Percentage passing size }_{2}\right)^{2}}{\left(\text { Percentage passing Size }_{1}\right)^{2}} \times \text { Size }_{1} \\
X \mu \mathrm{m}=\left(\frac{80 / 100}{83.719 / 100}\right)^{2} \times 500=456.56 \mu \mathrm{m} \text { at } 80 \%
\end{gathered}
$$

Table 3: gives the sieve analysis of the feed of reference mineral (Jiche granite) to the ball mill and Figure 2 is the plot of sieve size against \%cumulative retained and \%cumulative passing of reference ore.

Permutation using data from Table 3

If $1000 \mu \mathrm{m}=75.520$

The $X \mu \mathrm{m}=80 \%$

$$
X \mu \mathrm{m}=\left(\frac{80 / 100}{75.52 / 100}\right)^{2} \times 1000=1130 \mu \mathrm{m} \text { at } 80 \%
$$

Table 4: gives the sieve size analysis result of the feed to ball mill of reference ore using Gurum granite and Figure 3 is the plot of sieve size against \% cumulative retained and \% cumulative passing.

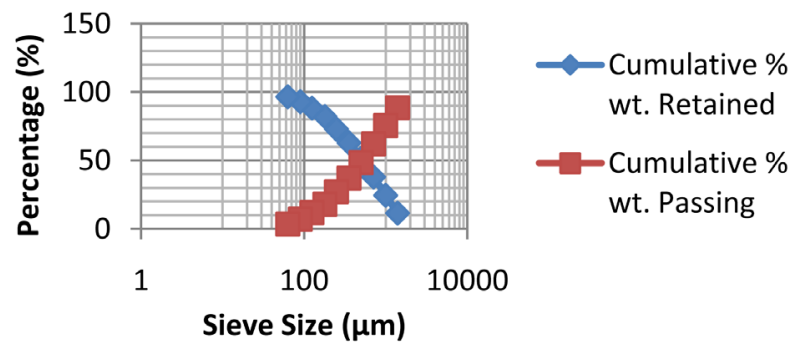

Figure 2. Plot of sieve size against \% cumulative retained and \% cumulative passing of Jiche granite as feed to ball mill.

Table 3. Sieve analysis of Jiche granite sample (reference ore) feed to ball mill.

\begin{tabular}{ccccc}
\hline Sieve Size $(\mu \mathrm{m})$ & Weight retained $(\mathrm{g})$ & \% Weight retained & \% Cumulative retained & \% Cumulative passing \\
\hline+1400 & 11.41 & 11.424 & 11.424 & 88.576 \\
$-1400+1000$ & 13.04 & 13.056 & 24.480 & 75.520 \\
$-1000+710$ & 13.43 & 13.446 & 37.926 & 62.074 \\
$-710+500$ & 13.64 & 13.656 & 51.582 & 48.418 \\
$-500+355$ & 11.33 & 11.344 & 62.926 & 37.074 \\
$-355+250$ & 9.95 & 9.962 & 72.888 & 27.112 \\
$-250+180$ & 9.21 & 9.221 & 82.109 & 17.891 \\
$-180+125$ & 6.13 & 6.137 & 88.246 & 11.754 \\
$-125+90$ & 4.73 & 4.736 & 92.982 & 7.018 \\
$-90+63$ & 3.61 & 3.614 & 96.596 & 3.404 \\
-63 & 3.40 & 3.404 & 100.0 & 0.00 \\
\hline
\end{tabular}




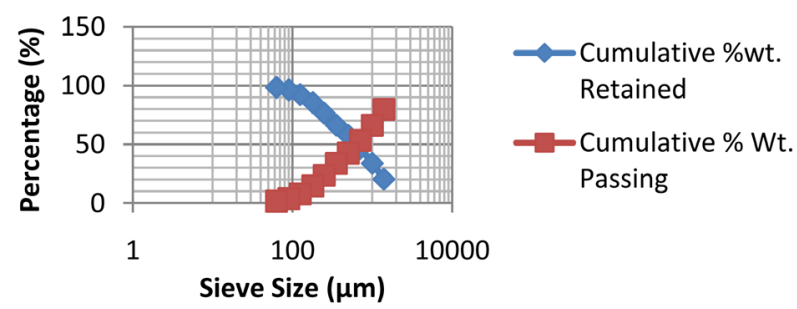

Figure 3. Plot of Sieve size against cumulative \% wt retained and cumulative \% wt passing of Gurum quartz feed to ball mill.

Table 4. Gives the sieve analysis of Gurum granite sample (reference ore) feed to ball mill.

\begin{tabular}{ccccc}
\hline Sieve size $(\mu \mathrm{m})$ & Weight retained $(\mathrm{g})$ & Weight $(\%)$ & Cumulative \% retained & Cumulative \% passing \\
\hline+1400 & 20.20 & 20.261 & 20.261 & 79.739 \\
$-1400+1000$ & 13.50 & 13.541 & 33.803 & 66.197 \\
$-1000+710$ & 12.70 & 12.738 & 46.534 & 53.466 \\
$-710+500$ & 10.90 & 10.932 & 57.466 & 42.534 \\
$-500+355$ & 8.80 & 8.826 & 66.292 & 33.708 \\
$-355+250$ & 10.10 & 10.130 & 76.422 & 23.578 \\
$-250+180$ & 9.00 & 9.027 & 85.449 & 14.551 \\
$-180+125$ & 6.80 & 6.820 & 92.269 & 7.731 \\
$-125+90$ & 4.00 & 4.012 & 96.281 & 3.719 \\
$-90+63$ & 2.10 & 2.106 & 98.387 & 1.605 \\
-63 & 1.60 & 1.605 & 100.00 & 0.00 \\
\hline
\end{tabular}

Calculations using data from Table 4

If $1400 \mu \mathrm{m}=79.739$

Then

$$
X \mu \mathrm{m}=\left(\frac{80 / 100}{79.74 / 100}\right)^{2} \times 1400=1413.74 \mu \mathrm{m} \text { at } 80 \%
$$

(B) Test Ore (Gyel Columbite)/References (Granites) Products as Discharge from the Ball Mill

Table 5: gives the sieve analysis of the product of test material in the ball mill (Gyel columbite) and Figure 4 is the plot of sieve size against the cumulative \% wt. retained and cumulative \% wt. passing of as-received Gyel columbite ore product from ball mill.

Calculations using data from Table 5

If $250 \mu \mathrm{m}=98.096$

Then $X \mu \mathrm{m}=80 \%$

$$
X \mu \mathrm{m}=\left(\frac{80 / 100}{98.1 / 100}\right)^{2} \times 250=166.26 \mu \mathrm{m} \text { at } 80 \%
$$

Table 6: shows the sieve analysis of the product of reference material (Jiche granite) of ball mill and Figure 5 is the plot of sieve size against \%cumulative retained and \%cumulative passing of reference ore product.

Calculation using data from Table 6

If $710 \mu \mathrm{m}=75.193$

Then $X \mu \mathrm{m}=80 \%$ 


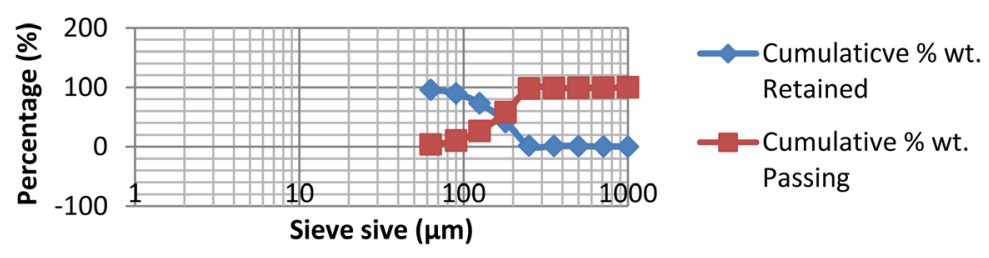

Figure 4. Shows the plot of sieve size against cumulative \% retained and cumulative \% passing of Gyel columbite ore product from ball mill.

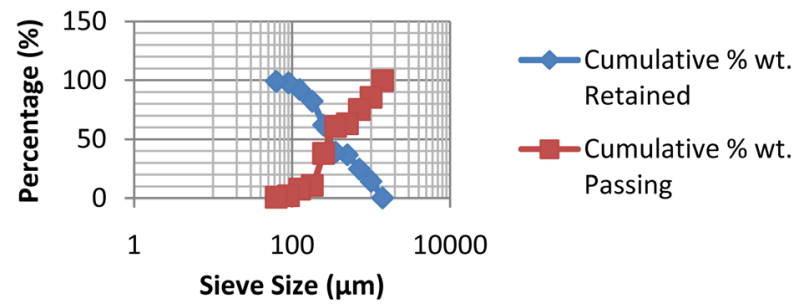

Figure 5. Shows the plot of Sieve size against cumulative \% retained and cumulative \% passing of Jiche granite product from ball mill.

Table 5. Sieve analysis of sample of columbite ore from Gyel village (product of test columbite) from the ball mill.

\begin{tabular}{|c|c|c|c|c|}
\hline Sieve size $(\mu \mathrm{m})$ & Weight retained (g) & \% Weight retained & Cumulative \% wt retained & Cumulative \% wt passing \\
\hline+1400 & - & - & - & - \\
\hline$-1400+1000$ & 0.12 & 0.120 & 0.120 & 99.880 \\
\hline$-1000+7100$ & 0.50 & 0.501 & 0.621 & 99.379 \\
\hline$-710+500$ & 0.41 & 0.411 & 1.032 & 98.968 \\
\hline$-500+355$ & 0.27 & 0.271 & 1.303 & 98.697 \\
\hline$-355+250$ & 0.60 & 0.601 & 1.904 & 98.096 \\
\hline$-250+180$ & 39.90 & 39.980 & 41.884 & 58.116 \\
\hline$-180+125$ & 31.40 & 31.463 & 73.347 & 26.653 \\
\hline$-125+90$ & 16.40 & 16.433 & 89.780 & 10.220 \\
\hline$-90+63$ & 6.30 & 6.313 & 96.093 & 3.908 \\
\hline \multirow[t]{2}{*}{-63} & 3.90 & 3.908 & 100.0 & 0.00 \\
\hline & 99.80 & & & \\
\hline
\end{tabular}

Table 6. Sieve analysis of Jiche granite sample (reference ore) product from ball mill.

\begin{tabular}{ccccc}
\hline Sieve size $(\mu \mathrm{m})$ & Weight retained $(\mathrm{g})$ & \% Weight retained & \% Cumulative retained & \% Cumulative wt passing. \\
\hline+1400 & 0.20 & 0.200 & 0.200 & 99.800 \\
$-1400+1000$ & 14.09 & 14.117 & 14.317 & 85.683 \\
$-1000+710$ & 10.47 & 10.490 & 24.807 & 75.193 \\
$-710+500$ & 11.93 & 11.953 & 36.760 & 63.240 \\
$-500+355$ & 2.32 & 2.324 & 39.084 & 60.916 \\
$-355+250$ & 22.81 & 22.853 & 61.937 & 38.063 \\
$-250+180$ & 27.32 & 27.372 & 82.309 & 10.691 \\
$-180+125$ & 2.76 & 2.765 & 92.074 & 7.920 \\
$-125+90$ & 5.80 & 5.811 & 97.885 & 2.115 \\
$-90+63$ & 1.31 & 1.312 & 99.197 & 0.803 \\
-63 & 0.80 & 0.803 & 100.0 & 0 \\
\hline
\end{tabular}




$$
X \mu \mathrm{m}=\left(\frac{80 / 100}{75.193 / 100}\right)^{2} \times 710=803.68 \mu \mathrm{m} \text { at } 80 \%
$$

Table 7: gives the sieve analysis of the product of test ore of the ball mill and Figure 6 is the plot of sieve size against the cumulative \% retained and cumulative \% passing of Gurum granite product from ball mill.

Calculations using data from Table 7

If $710 \mu \mathrm{m}=76.49$

Then $X \mu \mathrm{m}=80 \%$

$$
X \mu \mathrm{m}=\left(\frac{80 / 100}{76.49 / 100}\right)^{2} \times 710=776.66 \mu \mathrm{m} \text { at } 80 \%
$$

Using Bond's Equation (3.3)

$$
W_{i t}=W_{i r}\left[\frac{10}{\sqrt{P_{r}}}-\frac{10}{\sqrt{F_{r}}}\right] /\left[\frac{10}{\sqrt{P_{t}}}-\frac{10}{\sqrt{F_{t}}}\right]
$$

where, $W_{i r}=$ work index of the reference ore;

$W_{i t}=$ work index of test ore;

$P_{r}=$ the diameter of the reference ore product, $80 \%$ of which passes through $100 \mu \mathrm{m}$ aperture;

$P_{t}=$ the diameter of the test ore product, $80 \%$ of which passes through $100 \mu \mathrm{m}$ aperture;

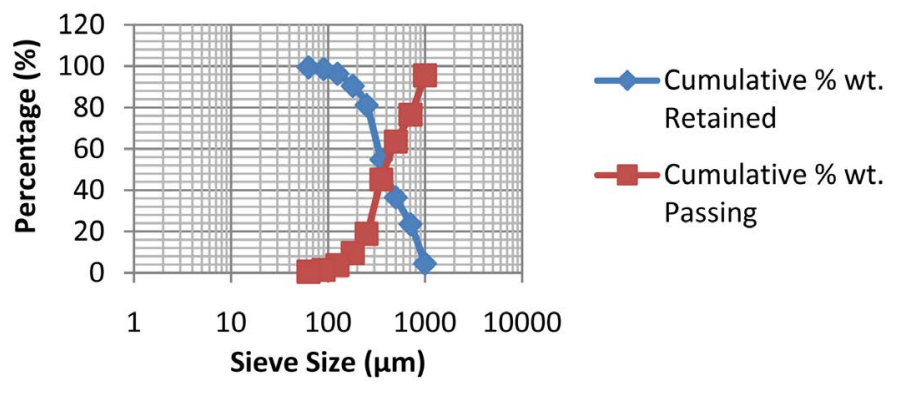

Figure 6. Shows the plot of sieve size against the cumulative \% retained and cumulative \% passing of Gurum granite product from the ball mill.

Table 7. Sieve analysis of Gurum granite sample (reference ore) product from the ball mill.

\begin{tabular}{ccccc}
\hline Sieve size $(\mu \mathrm{m})$ & Weight retained $(\mathrm{g})$ & \% Weight retained & \% Cumulative wt retained & \% Cumulative wt passing \\
\hline+1400 & - & - & - & - \\
$-1400+1000$ & 4.50 & 4.51 & 4.51 & 95.49 \\
$-1000+710$ & 19.00 & 19.04 & 23.55 & 76.45 \\
$-710+500$ & 12.90 & 12.93 & 36.48 & 63.52 \\
$-500+355$ & 18.30 & 18.34 & 54.82 & 45.18 \\
$-355+250$ & 26.20 & 26.25 & 81.07 & 18.93 \\
$-250+180$ & 9.30 & 9.32 & 90.39 & 9.61 \\
$-180+125$ & 5.90 & 5.91 & 96.30 & 3.70 \\
$-125+90$ & 2.30 & 2.30 & 98.60 & 1.40 \\
$-90+63$ & 0.80 & 0.80 & 99.40 & 0.60 \\
-63 & 0.60 & 0.60 & 100.0 & 0.00 \\
\hline
\end{tabular}


$F_{r}=$ the diameter of the reference ore feed, $80 \%$ of which passes through $100 \mu \mathrm{m}$ aperture;

$F_{t}=$ the diameter of the test ore feed, $80 \%$ of which passes through $100 \mu \mathrm{m}$ aperture;

$W_{r}=$ work input in kilowatt hour/short ton for reference ore and;

$W_{t}=$ work input in kilowatt hour/short ton for test ore.

Using Jiche granite as a reference ore and Gyel columbite ore as the test ore

$$
\begin{gathered}
P_{r}=803.68 \mu \mathrm{m} \\
F_{r}=1130 \mu \mathrm{m} \\
P_{t}=166.26 \mu \mathrm{m} \\
F_{t}=456.56 \mu \mathrm{m}
\end{gathered}
$$

$W_{i r}=15.13$ (granite work index value [4]).

Therefore:

$$
W_{i t}=15.13 \frac{(10 \sqrt{803.68}-10 \sqrt{1130.0})}{(10 \sqrt{166.26}-10 \sqrt{456.56})}=2.72 \mathrm{~kW} \cdot \mathrm{h}
$$

While using Gurum granite as a reference ore and Gyelcolumbite ore as the test ore

$$
\begin{gathered}
P_{r}=742.58 \mu \mathrm{m} \\
F_{r}=1404.56 \\
P_{t}=203.87 \\
F_{t}=477.79
\end{gathered}
$$

$W_{i r}=13.57$ (minimum value of the granite work index [4]).

Therefore:

$$
W_{i t}=13.57 \frac{(10 \sqrt{742.58}-10 \sqrt{1404.56})}{(10 \sqrt{203.87}-10 \sqrt{477.79})}=3.42 \mathrm{~kW} \cdot \mathrm{h} / \text { ton }
$$

\subsection{Discussion}

Tables 2-7 give the results and Figures 1-6 show the plots of the particle size analysis of the reference and test ores $80 \%$ passing for both the feeds and products sieves size fractions for the references and the Gyel columbite ores samples. The $80 \%$ passing particle size fraction for both feed and the product of the as-received Gyel columbite ore sample was found to be $456.56 \mu \mathrm{m}$ and $203.87 \mu \mathrm{m}$ respectively while the work index of the as received Gyel columbite ore sample was computed to be $3.42 \mathrm{kWh} /$ ton on the average which when compared to the work index of other columbite ores, the result obtained lies favourably within the work indexes of 3.94 $10.81 \mathrm{kWh} /$ ton for columbite and pyrochlore-coltan mineral ores sighted in the literatures [1] [4] [10]. The 3.42 $\mathrm{kWh} / \mathrm{ton}$ work index obtained for the Gyel columbite ore sample means that about $3.42 \mathrm{kWh}$ of energy is required to reduce one ton of the as-received Gyel columbite ore sample from $80 \%$ passing size of $456.56 \mu \mathrm{m}$ to 80\% passing size of $203.87 \mu \mathrm{m}$. Furthermore, using the Denver grindability test curves the Gyel columbite ore is classified as a medium soft texture type ore, because the work index of the as-received Gyel columbite ore sample grind for one hour cut through the curve line of the ore type "B" of the Denver grindability curves [11] [12].

\section{Conclusion}

In conclusion the work index of Gyel columbite ore sample from Jos, South Local Government Area of Plateau state, Nigeria has been determined and found to be $3.07 \mathrm{kWh} / \mathrm{ton}$ on average. This parameter is significant in the design of a process route for the beneficiation of the Gyel columbite ore sample. 


\section{References}

[1] Thomas, D.G., Asuke, F. and Yaro, S.A. (2014) Determination of Some Conceptual Mineral Processing Parameters of Soba-Wanka Pyrochlore-Col Tan Mineral Ore Deposit. 2014 Nigeria Engineering Conference, 15-18 August 2014, 2, 32-41.

[2] Ministry of Mines and Steel Development (2012) Road Map for the Development of Solid Minerals and Metals Sector. Stack Holders Forum, Abuja, 3, 4-9.

[3] Mallo, S.J. (2007) Mineral and Mining on the Jos Plateau. ACON Publishers, Charlottetown, 7-14.

[4] Wills, B.A. and Napier-Mum, T.J. (2006) Mineral Processing Technology. 7th Edition, Elsevier Science \& Technology Books, Amsterdam, 109-439.

[5] Mills, C. (2013) Particle Size Distribution and Liberation Size. http://www.technology.infomine.com/enviromine/ard/mineralogy/Size\%20\&\%20liberation

[6] Magdalimovic, N.M (1989) Calculation of Energy Required for Grinding in a Ball Mill. Journal of Mineral Processing, 25, 41-42. http://dx.doi.org/10.1016/0301-7516(89)90055-0

[7] One Mine (2010) Summary and Determination of the Bond Work Index Using an Ordinary Laboratory Batch Ball Mill. http://www.onemine.org/search/summary.cmf

[8] Berry, T.F. and Bruce, R.W. (1966) A Simple Method of Determining the Grindability of Ores. Canadian Mining Journal, 87, 63-65.

[9] Olatunji, K.J. and Durojaiye, A.G. (2010) Determination of Bond Index of Birnin-Gwari Iron Orein Nigeria. Journal of mineral and Materials Characterization and Engineering, 9, 635-642.

[10] Weiss, N.L. (1985) Particle Characterization, Mineral Processing Handbook. American Institute of Mining and Metallurgical, 1, 142-156.

[11] Mathur, G.P. (1985) Terminal Report. Central Metallurgical Research and Development Institute, 2, 12-17.

[12] Mills, C. (1995) Technical Review of the Acid Rock Drainage (ARD) and Metal Leaching Aspects of the Metallurgical Test Work, Milling Practices and Tailings Monitoring for the Huckleberry Project. Report to BC Ministry of Energy Mines and Petroleum Resources, 1, 34. 